\title{
The frequency of alopecia and quality of life in high-school students in rural areas (Sivrihisar, Mahmudiye, Alpu, and Beylikova) of Eskisehir
}

\author{
(D) Ozkan Ozay, ${ }^{1}$ (1) Didem Arslantas, ${ }^{2}$ (D) Alaeettin Unsal, ${ }^{2}$ (D) Isil Bulur ${ }^{3}$ \\ ${ }^{1}$ Ercis Community Health Center, Van, Turkey \\ ${ }^{2}$ Department of Public Health, Eskisehir Osmangazi University Faculty of Medicine, Eskisehir, Turkey \\ ${ }^{3}$ Department of Dermatology, Memorial Atasehir Hospital, Istanbul, Turkey
}

\begin{abstract}
OBJECTIVE: The aim of the present study was to determine the incidence of alopecia and related factors and the healthrelated quality of life (HRQoL) in high-school students in rural areas of Eskisehir. This was a cross-sectional study.

METHODS: The study was performed between March 2, 2015 and April 30, 2015. A total of 1662 (74.9\%) students were included in the study. The questionnaire performed for the purpose and consisted of four sections was filled out by the students themselves under supervision. The HRQoL was evaluated by Short Form-36 (SF-36). Students' hair and scalps were examined by a dermatologist. The acquired data were analyzed by SPSS 20 statistical package program. Chi-square test, Mann-Whitney $\mathrm{U}$ test, and logistic regression analyses were used for statistical analyses. A $p$ value $\leq 0.05$ was accepted as statistically significant.

RESULTS: In the present study, the incidence of alopecia was found to be $37.4 \%(n=622)$. Alopecia was more frequently seen in male students who have complaints about their scalps and those with a fatty scalp. In the study group, students with alopecia had poor HRQoL in general health perception, vitality, and mental health of SF-36.

CONCLUSION: There is a need to provide early diagnosis and treatment to decrease the incidence of alopecia and to improve the quality of life. Health education studies must be performed to increase the awareness of students about alopecia. Integrating hair and scalp examination into school health screening studies, steering the students who have alopecia to the dermatologists, and suggesting students who have fatty scalp regular hair washing will be appropriate.
\end{abstract}

Keywords: Adolescent; alopecia; Eskisehir; quality of life.

Cite this article as: Ozay $O$, Arslantas D, Unsal A, Bulur I. The frequency of alopecia and quality of life in high-school students in rural areas (Sivrihisar, Mahmudiye, Alpu, and Beylikova) of Eskisehir. North Clin Istanb 2019;6(3):226-235.

\section{A} dolescent (adolescence) period is a process in which rapid physical, biological, psychological, and emotional changes are experienced during transition from childhood to adulthood. The World Health Organization (WHO) defines the 10-19 age group as the adolescent period, and this period may vary from person to person; it is difficult to confine the adolescent period strictly within a certain age group because of the sociocultural and socioeconomic characteristics of the societies, geographic, and seasonal features of the living place and dietary habits of the communities [1-4].

According to the WHO's definition of adolescent, it is reported that 1 out of 5 people worldwide is in the adolescent age group, meaning approximately 1.2 billion 
people. Globally, $85 \%$ of adolescents live in developing countries. In most countries, adolescents account for $20 \%-25 \%$ of the population, whereas the adolescent age group accounts for $16.8 \%$ of Turkey's population [4-7]

While hormonal changes in the adolescent period cause physical growth and pubertal changes, significant psychosocial changes are also seen. This change, which begins in the second decade of life, varies according to gender, person, and society [4].

Adolescent period is a special period where both hair problems and other dermatological disorders are seen frequently because of the hormonal changes in human life and the intense life conditions of collective life as is seen in schools or dormitories. Hair problems lead to depression and anxiety in adolescents and young adults and may affect their health-related quality of life (HRQoL) adversely. Changes in the appearance and quality of hair as wearing, splitting, thinning of hair strands or vice versa, and hypertrichosis (excessive growth of hair) may be defined as hair problems $[1,4,8]$.

As generally known, congenital, infectious, autoimmune, genetic, and environmental factors are responsible for hair loss (alopecia). The known risk factors for alopecia are chronic endocrine or allergic diseases, surgery, regular drug use, nutrition, gynecological diseases, and stressful lifestyle $[8,9]$.

Physicians should identify the problem or any other underlying disease that causes hair loss accurately because of the lack of self-confidence and the quality of life caused by hair loss. Although it is important to evaluate alopecia in primary health care services, it is known that many physicians fail to evaluate and diagnose alopecia $[10,11]$.

Alopecia is categorized into two groups as those with and without scar, and most of them are cases with scarless alopecia. Androgenetic alopecia (AGA), telogen effluvium (TE), alopecia areata (AA), traction alopecia, and tinea capitis are grouped under the category of scarless alopecia, whereas discoid lupus erythematosus, lichen planus, infection (e.g., bacterial, viral, and fungal)induced alopecia, and alopecia secondary to trauma or burns are also grouped under the category of scarred alopecia. According to the amount of hair loss, alopecia is also classified as diffuse alopecia and focal alopecia. The most common subtypes of alopecia in adolescents are AGA and TE $[9,10,12,13]$.

The prevalence of alopecia in adolescents worldwide varies widely between $15.5 \%$ and $38.5 \%$ because of the diversity of societies with respect to their genetic, eth- nic, and lifestyle characteristics [14-17]. A field research related to the prevalence of alopecia has not been performed in Turkey.

The present study was conducted to determine the prevalence of alopecia among high-school students studying in the rural settlement of Eskisehir, to investigate the presumably related factors, and to evaluate the HRQoL of the study participants.

\section{MATERIALS AND METHODS}

This was a cross-sectional study on high-school students who were receiving education and training in high schools in four districts (Sivrihisar, Mahmudiye, Alpu, and Beylikova) situated at the center of Eskisehir province between March 2, 2015 and April 30, 2015. The total population of the research region is 46,869 people. The region is at a medium socioeconomic level, and generally, the livelihood of the people is agriculture and animal husbandry $[18,19]$.

The study constituted of high-school students grades 9-12 living and receiving education and training in the schools situated in the center of the districts of Sivrihisar, Mahmudiye, Alpu, and Beylikova. A total of 14 high schools were situated in the district centers, and a total of 2220 students were receiving education and training in these high schools. In our study, any sampling was not performed, and it was aimed to reach all students.

The study was approved by the ethics committee, and necessary permissions and appointments were received from the Provincial Directorate of National Education and High Schools. The students were allowed to attend and gather in the classes during the day and hours of the appointment. Students were informed about the subject and purpose of the study. Oral informed consent was obtained from the students who agreed to participate in the study.

The previously prepared questionnaire forms were filled up by the students themselves under surveillance in accordance with the purpose of the study. The questionnaire form consisted of four sections. Questions about some of the sociodemographic characteristics of the students were included in the first section. Some factors that are thought to be related to the presence of alopecia comprised the second section. Results of hair and scalp examination were recorded in the third section. The fourth section consisted of questions about Short Form-36 (SF-36) scale items. After completing the questionnaire survey, the height and body weights of the students were 
measured by the researchers. Then, the students' hair and scalp were examined by a dermatologist. The presence and severity of alopecia were assessed by examination. The severity of hair loss among those with alopecia was grouped as mild, moderate, and severe.

To make the diagnosis of TE, which is one of the subtypes of alopecia, skin pull test was performed [2022]. According to the dermoscopic examination of hair strands, students having hair strands with a diameter of $\leq 39 \mu \mathrm{m}, 40-79 \mu \mathrm{m}$, and $\geq 80 \mu \mathrm{m}$ were evaluated as those with thin, normal, and thick hair strands, respectively [23]. In the present study, the criteria in the Declaration of Helsinki have been complied with.

In our study, SF-36 was used in the evaluation of HRQoL. This scale was developed by Ware et al. in 1992 , and its validity and reliability study in Turkey was performed by Kocyigit et al. in 1999 [24, 25]. The SF36 is a self-evaluation scale, and the status of individuals within the last 4 weeks is taken as a basis. There are eight subdomains of the scale, including physical functioning, physical role, pain, general health, vitality, social functioning, mental role, and mental health. The higher the score from each subdomain, the higher the HRQoL of that subdomain $[26,27]$.

Data obtained were evaluated using the IBM SPSS statistical package program (International Business Machines for Social Sciences version 20.0; SPSS Inc., Chicago, IL, USA). Chi-square test and Mann-Whitney $U$ test were used for data analysis. Backward Stepwise (Wald) Logistic Regression Analysis was performed with some variables found to be related to the presence of alopecia. A p value $\leq 0.05$ was accepted as statistically significant.

\section{RESULTS}

A total of 2220 students were attending the high schools in the research area. Of the 2220 students, 463 could not be found in schools during the study period, and 95 were excluded from the study because they did not accept hair and scalp examination. The study group was composed of $1662(74.9 \%)$ students. The ages of the students ranged from 14 to 19 years, and the average age was $16.2 \pm 1.1$ years. In our study, the prevalence of alopecia was $37.4 \%(n=622)$.

The study group consisted of 906 (54.5\%) male and 756 (45.5\%) female students, and 493 (29.6\%) students were aged $\leq 15$ years. Of the 1662 students, $349(21.0 \%)$ were smokers, and 179 (10.8\%) were drinking alcohol. A total of $262(15.8 \%)$ students had physician-diagnosed chronic diseases. Table 1 shows the distribution of alopecia in the study group according to some sociodemographic characteristics.

Of the 1662 students, 1422 (85.6\%) had been living in a core family, and $240(14.4 \%)$ had been living in a large family. More than half of the students reported that their family was at a moderate income level. Mothers of $250(15.0 \%)$ and fathers of $1256(75.6 \%)$ students were employed. Mothers of 1147 (69.0\%) students had received primary education (or lower level). However, fathers of $856(51.2 \%)$ students were secondary and high-school graduates, and 927 (55.8\%) students were living with their families. Table 2 shows the distribution of alopecia among the study groups according to some parental characteristics.

In the study group, 419 (25.2\%) students were complaining of burning, stinging, and itching sensations on the scalp, whereas $835(50.2 \%)$ students were using hair dryer after shower/bath, and 409 (24.6\%) students were using chemical hair styling products. Table 3 shows the distribution of alopecia in the study group according to some factors related to hair health.

According to the results of scalp examination, 938 (56.4\%) students had thin, 633 (38.1\%) had thick, and 91 (5.5\%) had normal hair strands. According to the results of scalp examination, 780 (46.9\%) students had natural, 563 (33.9\%) had greasy, 253 (15.2\%) had dry, and $66(4.0 \%)$ had moist hair.

Table 4 presents the distribution of hair strand thickness and scalp type in patients with and without alopecia.

Among the students with alopecia, 385 (23.2\%) had AGA, 171 (10.3\%) had TE, 40 (2.4\%) had triangular (TAA), $37(2.2 \%)$ had traction, $17(1.0 \%)$ had scleral, and $4(0.2 \%)$ had androgenic alopecia. In the study group, the distribution of students with alopecia according to alopecia subtypes is given in Figure 1.

In the study group, the results of logistic regression analysis that is performed with the variables (sex, age group, smoking status, presence of complaint in the scalp, hair thickness, and scalp type) found to be related to the presence of alopecia are given in Table 5.

In our study, according to the results of logistic regression analysis, gender, presence of scalp, and type of scalp were found to be risk factors for the incidence of alopecia. 


\section{TABLE 1. Distribution of study participants with and without alopecia according to their sociodemographic characteristics}

\begin{tabular}{|c|c|c|c|c|c|c|c|}
\hline Some sociodemographic characteristics & \multicolumn{6}{|c|}{ Alopecia } & $\begin{array}{c}\text { Test value } \\
\mathrm{X}^{2} ; \mathrm{p}\end{array}$ \\
\hline \multicolumn{8}{|l|}{ Gender } \\
\hline Male & 378 & 41.7 & 528 & 58.3 & 906 & 54.5 & $15.704 ; 0.001$ \\
\hline \multicolumn{8}{|l|}{ Age group } \\
\hline$\leq 15$ years & 172 & 34.9 & 321 & 65.1 & 493 & 29.6 & \multirow{4}{*}{$8.462 ; 0.037$} \\
\hline 16 years & 165 & 34.4 & 314 & 65.6 & 479 & 28.8 & \\
\hline 17 years & 192 & 40.2 & 286 & 59.8 & 478 & 28.8 & \\
\hline$\geq 18$ years & 93 & 43.9 & 119 & 56.1 & 212 & 12.8 & \\
\hline \multicolumn{8}{|l|}{ Smoking status } \\
\hline \multicolumn{8}{|l|}{ Alcohol consumption } \\
\hline Yes & 78 & 43.6 & 101 & 56.4 & 179 & 10.8 & \multirow{2}{*}{$3.241 ; 0.072$} \\
\hline No & 544 & 36.7 & 939 & 63.3 & 1483 & 89.2 & \\
\hline \multicolumn{8}{|c|}{ Presence of physician-diagnosed chronic disease } \\
\hline Yes & 101 & 38.5 & 161 & 61.5 & 262 & 15.8 & \multirow{3}{*}{$0.168 ; 0.682$} \\
\hline No & 521 & 37.2 & 879 & 62.8 & 1400 & 84.2 & \\
\hline Total & 622 & 37.4 & 1040 & 62.6 & 1662 & 100.0 & \\
\hline
\end{tabular}

*Percentage of the row; **Percentage of the column.

In the study group, there were no differences in the scores obtained in the subdomains other than the general health, vitality, and mental health subdomains. Table 6 presents the distribution of the median scores obtained from the subdomains of the SF-36 scale in the study group.

\section{DISCUSSION}

Alopecia, which can be seen in men and women of all ages, is a dermatological problem observed in approximately half of the people throughout their lives. Although alopecia is not a life-threatening condition, hair loss can often lead to adverse social and psychological consequences due to the fact that hair is an important social communication tool, and hair loss adversely affects selfconfidence and the quality of life of individuals $[10,11]$.

Owing to the increase in androgenic hormonal activity and psychosocial changes, the incidence of alopecia in adolescence has increased significantly $[4,28,29]$. In our study, the incidence of alopecia was $37.4 \%$. In studies conducted in various countries, the incidence of alopecia in adolescents has been reported to range from $15.5 \%$ to $38.5 \%$ [14-17]. The reasons of the different results reported in various studies may be considered as the differences in sociodemographic, ethnic, genetic, and lifestyle characteristics of the societies in which the studies are conducted and the differences in the diagnostic methods used. AGA is the most common alopecia subtype in adolescence and afterwards. Androgenic hormones trigger alopecia by miniaturizing strong terminal hairs, and as a result, alopecia is expected to be more common in men [29-31]. In our study, the incidence of alopecia was higher in male than in female students $(\mathrm{p} \leq 0.05$, odds ratio $(\mathrm{OR})=1.367)$. Paik et al. and Xu et al. reported similar results $[32,33]$. Agirgol et al. reported that there is no relationship between the frequency of alopecia and gender [34].

There was no correlation between the frequency of alopecia and age group in the study group $(p>0.05)$. 
TABLE2. Distribution of study participants with and without alopecia according to some parental characteristics

Some parental characteristics

\begin{tabular}{|c|c|c|c|c|c|c|}
\hline \multicolumn{6}{|c|}{ Alopecia } & \multirow[t]{2}{*}{ Test value } \\
\hline & & & & & & \\
\hline$n$ & $\% *$ & $\mathrm{n}$ & $\% *$ & $\mathrm{n}$ & $\% * *$ & $x^{2} ; p$ \\
\hline
\end{tabular}

Family type

Core

Large

Income level of the family

Poor

Moderate

Good

Employment status of the mother

Employed

Unemployed

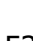

Employment status of the father

Employed

Unemployed

Educational level of the mothers

Primary school and lower

Secondary school and higher

Educational level of the fathers

Primary school and lower

Secondary school and higher

533

89

37.5

37.1

889

151

$62.5 \quad 1422$

85.6

$\begin{array}{lll}62.9 & 240 & 14.4\end{array}$

$0.014 ; 0.906$

36

42.9

48

57.1

84

5.1

$438 \quad 38.1 \quad 713$

61.9

1151

69.3

$2.646 ; 0.266$

148

$\begin{array}{ll}34.7 & 279\end{array}$

65.3

427

25.7

$95 \quad 38.0 \quad 155$

$527 \quad 37.3 \quad 885$

$62.0 \quad 250$

15.0

$\begin{array}{lll}62.7 & 1412 \quad 85.0\end{array}$

$0.042 ; 0.838$

$\begin{array}{llllll}471 & 37.5 & 785 & 62.5 & 1256 & 75.6\end{array}$

$151 \quad 37.2 \quad 255$

62.8

405

24.4

$0.012 ; 0.911$

$\begin{array}{llllll}430 & 37.5 & 717 & 62.5 & 1147 & 69.0\end{array}$

$\begin{array}{llllll}192 & 37.3 & 323 & 62.79 & 515 & 31.0\end{array}$

$0.007 ; 0.936$

$\begin{array}{llllll}319 & 39.3 & 492 & 60.7 & 811 & 48.8\end{array}$

$\begin{array}{llllll}303 & 35.6 & 548 & 64.4 & 851 & 51.2\end{array}$

$2.466 ; 0.116$

Place of residence

With his family

Dormitory

361

261

$38.9 \quad 566$

566
474

61.1

927

55.8

Total

$622 \quad 37.4 \quad 1040$

$64.5 \quad 735$

44.2

$\begin{array}{lll}62.6 & 1662 & 100.0\end{array}$

$2.063 ; 0.151$

*Percentage of the row; **Percentage of the column.

Kyriakis et al, reported results similar to our study [35]. Price et al. reported an increase in the incidence of alopecia with aging [36]. Kim et al. reported that the incidence of alopecia in the 14-18 age group is higher than that in the 10-14 age group [37]. In our study, the relationship between the age group and the incidence of alopecia could not be determined due to the fact that the age groups were very close to each other.

The poor socioeconomic status of the family and the poor environmental characteristics of the living place are risk factors that increase the incidence of alopecia [38]. In our study, there was no relationship between the incidence of alopecia and family type, family income level, parental working status, parental education level, and place of residence ( $p>0.05$, for each). Similar studies have reported the lack of any correlation between the socioeconomic characteristics, such as family type, family income, and parental education, and the incidence of alopecia $[39,40]$. Since the schools included in the study were in rural areas and the individuals living there had similar socioeconomic and environmental characteristics, any correlation between the parental characteristics and the incidence of alopecia could not be found.

The chemical substances contained in the cigarette can cause free radicals to break down the capillary structure, reduce the blood supply, and impair nutrition of the hair follicles. Alcohol consumption can also damage the hair follicles by increasing oxidative stress and reducing protein synthesis. Smoking and alcohol consumption may cause alopecia due to these reasons [41-44]. Simi- 
TABLE 3. Distribution of study participants with and without alopecia according to some factors related to hair health

Some factors related to hair health

\begin{tabular}{|c|c|c|c|c|c|c|}
\hline \multicolumn{6}{|c|}{ Alopecia } & \multirow[t]{2}{*}{ Test value } \\
\hline & & & & & & \\
\hline$n$ & \%* & $\mathrm{n}$ & \%* & $\mathrm{n}$ & $\% * *$ & $x^{2} ; p$ \\
\hline
\end{tabular}

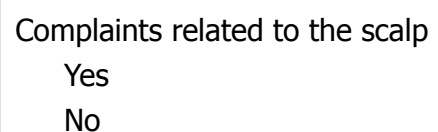

Use of hair dryer

Users

Non-users

Use of hair styling products

Users

Non-users

Total

\begin{tabular}{lcccccc}
174 & 41.5 & 245 & 58.5 & 419 & 25.2 & $\mathbf{4 . 0 2 7} \mathbf{0 . 0 4 5}$ \\
448 & 36.0 & 795 & 64.0 & 1243 & 74.8 & \\
& & & & & & \\
311 & 37.2 & 524 & 62.8 & 835 & 50.2 & $0.023 ; 0.879$ \\
311 & 37.6 & 516 & 62.8 & 827 & 49.8 & \\
& & & & & & \\
144 & 35.2 & 265 & 64.8 & 409 & 24.6 & \\
478 & 38.1 & 775 & 61.9 & 1253 & 75.4 & $1.139 ; 0.286$ \\
622 & 37.4 & 1040 & 62.6 & 1662 & 100.0 & \\
\hline
\end{tabular}

*Percentage of the row; **Percentage of the column.

TABLE 4. Distribution of students with and without alopecia according to hair strand thickness and scalp type

Hair strand thickness and scalp type

\begin{tabular}{|c|c|c|c|}
\hline \multicolumn{3}{|c|}{ Alopecia } & Test value \\
\hline Yes & No & Total & \\
\hline$\% *$ & $\% *$ & $\% * *$ & $\mathrm{X}^{2} ; \mathrm{p}$ \\
\hline
\end{tabular}

Thickness of the hair strand

Thin

Normal

Thick

Scalp type

Natural

Dry

Moist

Fatty

Total

$\begin{array}{cccccc}356 & 38.0 & 582 & 62.0 & 938 & 56.4 \\ 22 & 24.2 & 69 & 75.8 & 91 & 5.5 \\ 244 & 38.5 & 389 & 61.5 & 633 & 38.1 \\ & & & & & \\ 251 & 32.2 & 529 & 67.8 & 780 & 46.9 \\ 97 & 38.3 & 156 & 61.7 & 253 & 15.2 \\ 24 & 36.4 & 42 & 63.6 & 66 & 4.0 \\ 250 & 44.4 & 313 & 55.6 & 563 & 33.9 \\ 622 & 37.4 & 1040 & 62.6 & 1662 & 100.0\end{array}$

7.273; 0.026

*Percentage of the row; **Percentage of the column.

lar studies have also reported the lack of any relationship between smoking and alcohol consumption and the incidence of alopecia [43-46]. Mosley et al. reported that the incidence of alopecia is higher in smokers [47].

Severi et al. reported that the incidence of alopecia is higher in alcohol consuming individuals, and that alcohol consumption is associated with AGA, especially involv- ing the forehead and vertex, and not related to the other types of alopecia [43]. Owing to the smaller age of the students in the study group and the time required for the observation of the cumulative effects of cigarette and alcohol on alopecia did not pass, the relationship between smoking and alcohol consumption and the frequency of alopecia might not be found in our study. 
TABLE 5. Results of logistic regression analysis performed using variables detected to be related to alopecia

\begin{tabular}{lcccrr} 
Variables & $\beta$ & SE & p & OR & $95 \%$ CI \\
\hline $\begin{array}{l}\text { Gender (reference: female students) } \\
\quad \text { Male students }\end{array}$ & 0.313 & 0.113 & $\mathbf{0 . 0 0 5}$ & 1.367 & $1.097-1.705$ \\
$\begin{array}{l}\text { Complaints related to the scalp (reference: none) } \\
\quad \text { Yes }\end{array}$ & 0.265 & 0.121 & $\mathbf{0 . 0 2 8}$ & 1.303 & $1.029-1.650$ \\
$\begin{array}{l}\text { Scalp types (reference: natural) } \\
\quad \text { Dry }\end{array}$ & & & 0.486 & 1.210 & $0.708-2.066$ \\
$\quad$ Moist & & 0.100 & 1.294 & $0.952-1.759$ \\
$\quad$ Fatty & - & 0.001 & 1.586 & $1.257-2.001$ \\
$\quad$ Constant & 1.441 & & 0.381 & 0.000 & - \\
\end{tabular}

SE: Standard error; OR: Odds ratio; CI: Confidence interval.

TABLE 6. Distribution of median scores obtained by study participants with and without alopecia from SF-36 scale subdomains

SF-36 subdomains

Alopecia

Test value

\begin{tabular}{ccc}
\hline Yes & No & z; p \\
Median (Min.-Max.) & Median (Min.-Max.)
\end{tabular}

Physical functioning

$90.0(0.0-100.0)$

$95.0(0.0-100.0)$

$1.370 ; 0.171$

Physical role

$75.0(0.0-100.0)$

$100.0(0.0-100.0)$

$1.755 ; 0.079$

Pain

$80.0(0.0-100.0)$

$87.5(0.0-100.0)$

$1.785 ; 0.074$

General health

$60.0(0.0-100.0)$

$65.0(0.0-100.0)$

1.968; 0.049

Vitality

$60.0(0.0-100.0)$

$65.0(0.0-100.0)$

2.326; 0.020

Social functioning

$75.0(0.0-100.0)$

$75.0(0.0-100.0)$

$1.397 ; 0.162$

Mental role

$66.7(0.0-100.0)$

$66.7(0.0-100.0)$

$1.396 ; 0.163$

Mental health

$56.0(0.0-100.0)$

$60.0(0.0-100.0)$

$3.007 ; 0.003$

Min.: Minimum; Max.: Maximum.

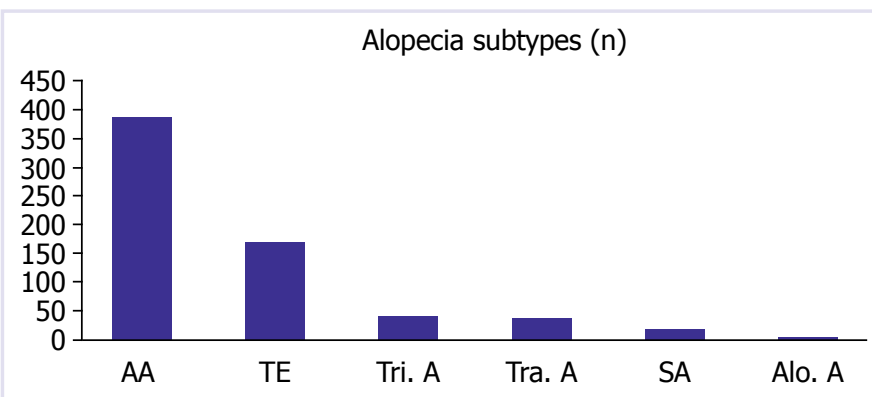

AA: Androgenetic alopecia; TE: Telogen effluvium; Tri. A: Triangular alopecia; Tra. A: Traction alopecia; SA: Scarred alopecia; Alo. A: Alopecia areata.

FIGURE 1. In the study group, the distribution of students with alopecia according to alopecia subtypes.
Chronic diseases, such as hypothyroidism, hyperthyroidism, thyroiditis, hypertension, and diabetes, cardiovascular diseases, anemia, vascular structure, and autoimmune diseases cause $\mathrm{T}$ lymphocyte-mediated hair follicle damage and increase the risk of the development of alopecia [48-51]. There was no significant difference in the prevalence of alopecia among patients with physician-diagnosed chronic disease $(\mathrm{p}>0.05)$. Similar results have been reported in various studies $[28,52,53]$. Akbas et al. emphasized that the incidence of AA is found to be higher in patients with autoimmune thyroid diseases, atopic dermatitis, vitiligo, pernicious anemia, and chronic AA [19]. In the present study, the reasons of not 
finding a relationship between the presence of chronic disease and the incidence of alopecia can be related to the small age of the students, the onset of chronic illnesses in general in advanced ages, and the cumulative emergence of the alopecic effects of chronic diseases.

Burning, stinging, and itching sensations felt on the scalp can be caused by scalp lesions, and these lesions may lead to impaired nutrition oxygenation, and integrity of the scalp. In addition, the presence of a complaint or lesion involving the scalp can cause mechanical trauma because of the continuous playing with the hair and scratching of the scalp. It is expected that the presence of complaints related to the scalp will increase the incidence of alopecia due to these effects [19]. In the study group, the frequency of alopecia was higher in those with complaints related to the scalp than in those without $(p \leq 0.05, O R=1.303)$. It has been reported that the incidence of alopecia is higher in patients with symptoms, such as pruritus, burning, and stinging sensations, felt on the scalp and those with sensitive scalp skin $[19,54,55]$.

The use of a hair dryer, especially at high temperatures, is known to induce alopecia by causing deformities and fractures in the hair shaft. The use of a hair dryer at high temperatures to shape hair causes the hair follicles to burn, creating a special type of alopecia called "hot comb alopecia" $[56,57]$. In the study group, there was no difference in the frequency of alopecia between the hair dryer users and non-users ( $p>0.05)$. Whiting et al. and Jan et al. reported that the use of a hair dryer at high temperatures causes alopecia due to its traumatic effect [58, 59]. Since the students participating in the study group used a hair dryer at low temperatures to dry their hair after a bath/shower, not for the purpose of hot combing, we did not find any difference in the incidence of alopecia between users and non-users of hair dryers.

Chemical hair styling products, such as jelly, grease, and hairspray, can lead to alopecia by causing irritation and allergic reaction on the scalp and destroying keratin protein, an important component of the hair strand [60, 61]. In our study, no difference was found in the incidence of alopecia among those who used and did not use chemical hair styling products $(p>0.05)$. Similar results were reported in the study by Gummer et al. [62]. Draelos et al. and Zviak et al. reported higher incidence of alopecia among users of chemical hair styling products $[63,64]$. In the present study, the reasons of not finding a difference in the frequency of alopecia between users and non-users of chemical hair styling products may be re- lated to our study group being composed of adolescents. In addition, owing to the shorter follow-up period, we could not observe the side effects of these products, and our study population living in rural areas could not afford for these products due to economic concerns.

Thin hair strand is a sign of miniaturization in the hair follicle, causing the hair to become more fragile, and may lead to alopecia. The development of alopecia is facilitated with greater volume of hair loss with aging in people with thick hair $[65,66]$. In the present study, there was no relationship between the thickness of hair follicle and the frequency of alopecia $(p>0.05)$. Several studies have reported that the incidence of alopecia is higher in those with thin hair strands $[67,68]$. Courtois et al. and Barman et al. reported that alopecia is more frequently detected in patients with thicker hairs $[65,69]$. Different results obtained in various studies may be due to the difference in examination methods.

The sebum, which is produced by the sebaceous glands in the scalp, has a rich fat content and protects the scalp from mechanical trauma as it acts as a physical barrier by providing the lubrication of the scalp. In case of excessive secretion of the sebum, the hair follicles may become clogged, and the oxygenation and blood supply of the hair may be reduced with the potential increase in the risk of alopecia $[70,71]$. In the study group, the incidence of alopecia was higher in patients with oily/greasy hair ( $\mathrm{p} \leq 0.05, \mathrm{OR}=1.586)$. Ronny et al. and Pireard et al. reported that alopecia is more common in those with oily-haired skin $[72,73]$. Banka et al. reported that any correlation is not found between the incidence of scalp type and alopecia [74].

Owing to the increased activation of androgenic hormones during puberty, terminal hairs in hair follicles can turn into miniature hairs and induce the development of AGA. It is known that changes in thyroid and androgenic hormone metabolism play an important role in TE etiology. The most common alopecia subtypes due to hormonal changes occurring during and after adolescence are AGA and TE $[28,30,75,76]$. In the present study, the incidence rates of AGA and AA were $23.2 \%$ and $10.3 \%$, respectively. In some studies, the incidence rates of AGA and TE have been reported to range between 13.1 and $24.5 \%$ [32, 36, $77]$ and 1.6 and $59.7 \%$, respectively $[19,78]$. The reasons of the different results reported in various studies may be due to the sociodemographic and ethnic characteristics, lifestyles of the study populations investigated, and different diagnostic methods used in these studies. 
Since the body's perception of people is negatively affected by alopecia, their self-esteem decreases, which is known to affect the quality of life adversely leading to psychological and social problems $[11,79]$. In the study group, the SF-36 scale scores indicated the presence of a worse quality of life in the general health, vitality, and mental health subdomains of patients with alopecia $(p \leq 0.05$, for each). In the other subdomains of the scale, no difference was found with respect to the quality of life among those who were not identified with alopecia ( $p>0.05$, for each).

Gulec et al. reported poorer quality of life in the subdomains of vitality and mental health in those with alopecia [80]. Hollanda et al. reported that patients with alopecia are found to have poorer quality of life in the mental health, mental role, social function, and pain subdomains [81].

\section{Conclusion}

In the present study, owing to the high prevalence of alopecia, we deemed it appropriate to conduct health education studies, to integrate hair and scalp examinations into school screening programs, to direct students with alopecia to the dermatologists, to make students with fatty scalp to wash their hair regularly to improve the quality of life of the students in the research region, and to increase the awareness of students so as to increase the rates of early diagnosis and treatment.

Conflict of Interest: The authors declare no conflict of interest.

Financial Disclosure: The authors have no proprietary or financial interest in any products used in this study.

Authorship Contributions: Concept - OO, DA, AU, IB; Design OO, DA; Supervision - OO, DA; Materials - OO, DA, AU, IB; Data collection and/or processing - OO, IB; Analysis and/or interpretation - OO, DA, AU; Writing - OO, DA; Critical review - OO, DA, AU.

\section{REFERENCES}

1. Stevens-Simon C. Clinical applications of adolescent female sexual development. Nurse Pract 1993;18:18, 21, 25-9. [CrossRef]

2. Tecce N, Pane A. [Notes on morbidity of Heine-Medin disease in the province of Naples in the ten-year period1947-1956]. [Indexed for MEDLINE]. Acta Med Ital Mal Infett Parassit 1957;12:324-32.

3. Cotrufo P, Pezzullo C, Tecce N, Villari A. [Preliminary note on the influenzal epidemic in the province of Naples in August \& September, 1957]. [Article in Italian]. Acta Med Ital Mal Infett Parassit 1957;12:300.

4. Özcebe H. Birinci basamakta adölesan sorunlarına yaklaşım. Sted 2002:11:374-7.

5. Başer M. Adölesan cinselliği ve gebelik. C.Ü. Hemşirelik Yüksekokulu Dergisi 2000:4:50-4.

6. Colucci Cf, Jacono G, Tecce N. [Influenza epidemic of 1952-53 in the island of Procida; epidemiologic, virologic and serologicresearch]. [Article in Italian]. Riv Ist Sieroter Ital 1954;29:348-60.

7. Tecce N, Villari A. [Statistical contribution to the spread of intestinal parasitosis]. [Article in Italian]. Acta Med Ital Mal Infett Parassit 1957;12:150-6.

8. Hawryluk EB, English JC 3rd. Female adolescent hair disorders. J Pediatr Adolesc Gynecol 2009;22:271-81. [CrossRef]

9. Grimes DA, Blankenship O, Kremer C, Reese S, Sonstein F. Initial Office Evaluation of Hair Loss in Adult Women. The Journal for Nurse Practitioners 2011:7:456-62. [CrossRef]

10. Mounsey AL, Reed SW. Diagnosing and treating hair loss. Am Fam Physician 2009;80:356-62.

11. Springer K, Brown M, Stulberg DL. Common hair loss disorders. Am Fam Physician 2003;68:93-102.

12. Shapiro J, Wiseman M, Lui H. Practical management of hair loss. Can Fam Physician 2000;46:1469-77.

13. Bedocs LA, Bruckner AL. Adolescent hair loss. Curr Opin Pediatr 2008;20:431-5. [CrossRef]

14. Khumalo NP, Jessop S, Gumedze F, Ehrlich R. Hairdressing and the prevalence of scalp disease in African adults. Br J Dermatol 2007;157:981-8. [CrossRef]

15. Pathomvanich D, Pongratananukul S, Thienthaworn P, Manoshai S. A random study of Asian male androgenetic alopecia in Bangkok, Thailand. Dermatol Surg 2002;28:804-7. [CrossRef]

16. Rhodes T, Girman CJ, Savin RC, Kaufman KD, Guo S, Lilly FR, et al. Prevalence of male pattern hair loss in 18-49 year old men. Dermatol Surg 1998;24:1330-2. [CrossRef]

17. Setty LR. Hair patterns of scalp of white and Negro males. Am J Phys Anthropol 1970;33:49-55. [CrossRef]

18. http://www.alpu.bel.tr/. Accessed at 19.04.2015.

19. Akbaş A, Kılınç F, Yakut İ, Metin A. Türk Çocuklarında Görülen Saç Hastalıkları: Retrospektif Bir Analiz. Dermatoz 2014:4:1-8.

20. Fiedler VC, Gray AC. Diffuse alopecia: telogen hair loss. In: Olsen EA, editor. Disorders of Hair Growth: Diagnosis and Treatment. $2^{\text {nd }} \mathrm{ed}$. New York: McGraw-Hill; 2003. p.303-20.

21. Olsen EA. Disorders of hair growth: diagnosis and treatment. New York: McGraw-Hill, 2003.

22. Sinclair R, Banfield C, Dawber RPR. Handbook of Diseases of the Hair and Scalp. Oxford: Blackwell Science; 1999.

23. Oura $H$, Iino M, Nakazawa $Y$, Tajima M, Ideta R, Nakaya Y, et al. Adenosine Increases Anagen Hair Growth and Thick Hairs in Japanesewomen With Female Pattern Hair Loss: A Pilot, Double-Blind, Randomized, Placebo-Controlled Trial. J Dermatol 2008;35:763-7. [CrossRef]

24. Koçyiğit H, Aydemir Ö, Ölmez N, Memiş A. Kısa Form-36 (KF36)'nın Türkçe Versiyonunun Güvenilirliği ve Geçerliliği. İlaç ve Tedavi Dergisi 1999;12:102-6.

25. Ware JE Jr, Sherbourne CD. The MOS 36-item short-form health survey (SF-36). I. Conceptualframework and item selection. Med Care 1992;30:473-83. [CrossRef]

26. Carr AJ, Thompson PW, Kirwan JR. Quality of life measures. Br J Rheumatol 1996;35:275-81. [CrossRef]

27. Keller SD, Bayliss MS, Ware JE Jr, Hsu MA, Damiano AM, Goss TF. Comparison of responses to SF-36 Health Survey questions with oneweekand four-week recall periods. Health Serv Res 1997;32:367-84.

28. Bolognia JL, Jorizzo JL, Rapini RP. Dermatología. $1^{\text {st }}$ ed. Madrid: Elsevier.2004.

29. Randall V. Physiology and pathophysiology of androgenetic alopecia. Endocrinology; 2005. p. 2257-68.

30. Kaufman KD. Androgens and alopecia. Mol Cell Endocrinol 2002;198:89-95. [CrossRef]

31. Trüeb RM. Molecular mechanisms of androgenetic alopecia. Exp Gerontol 2002;37:981-90. [CrossRef] 
32. Paik JH, Yoon JB, Sim WY, Kim BS, Kim NI. The prevalence and types of androgenetic alopecia in Korean men and women. Br J Dermatol 2001;145:95-9. [CrossRef]

33. Xu F, Sheng YY, Mu ZL, Lou W, Zhou J, Ren YT, et al. Prevalence and types of androgenetic alopecia in Shanghai, China: a community-based study. Br J Dermatol 2009;160:629-32. [CrossRef]

34. Ağırgöl Ş, Baş Y, Azaklı HN, Geyik N, Karaoğlu A, Derviş E, et al. Alopesi Areatada Klinik Özellikler ve Tiroid Otoimmünitesi Sıklığı. Turkiye Klinikleri J Dermatol 2013;23:1-6.

35. Kyriakis KP, Paltatzidou K, Kosma E, Sofouri E, Tadros A, Rachioti E. Alopecia Areata Prevalence by Gender and Age. J Eur Acad Dermatol Venereol 2009;23:572-3. [CrossRef]

36. Price VH.Androgenetic alopecia in adolescents. Cutis 2003;71:115-21.

37. Kim BJ, Kim JY, Eun HC, Kwon OS, Kim MN, Ro BI. Androgenetic alopecia in adolescents: a report of 43 cases. The Journal of dermatology 2006:33:696-9. [CrossRef]

38. Sehgal VN, Srivastava G, Aggarwal A, Sethi G, Adhikari T. Alopecia areata in the Indian subcontinent. Skinmed 2007;6:63-9. [CrossRef]

39. Bilgiç Ö, Kaya K, Akça ÖF, Polat R. Alopesi Areatalı Hastalarda Psikiyatrik Belirtiler. Dermatoz 2011;2:227-9.

40. Güz H, Ay M, Dilbaz N. Bir Grup Dermatolojik Hastalarda Aleksitimi, Depresyon ve Anksiyete. Düşünen Adam 2001;14:99-103..

41. Cylwik B, Chrostek L, Szmitkowski M. [The effect of alcohol on iron metabolism]. [Article in Polish]. Pol Merkur Lekarski 2008;24:561-4.

42. Delibaş N, Özcankaya R. Serbest radikaller. SDÜ Tıp Fakültesi Dergisi 1995;2:11-7.

43. Severi G, Sinclair R, Hopper JL, English DR, McCredie MR, Boyle P, et al. Androgenetic alopecia in men aged 40-69 years: prevalence and risk factors. Br J Dermatol 2003;149:1207-13. [CrossRef]

44. Su LH, Chen TH. Association of androgenetic alopecia with smoking and its prevalence among Asianmen: a community-based survey. Arch Dermatol 2007;143:1401-6. [CrossRef]

45. Arias-Santiago S, Gutiérrez-Salmerón MT, Castellote-Caballero L, Buendía-Eisman A, Naranjo-Sintes R. Androgenetic alopecia and cardiovascular risk factors in men and women: a comparative study. J Am Acad Dermatol 2010;63:420-9. [CrossRef]

46. $\mathrm{Su} \mathrm{LH}$, Chen HH. Androgenetic alopecia in policemen: higher prevalence and different risk factorsrelative to the general population (KCIS no. 23). Arch Dermatol Res 2011;303:753-61. [CrossRef]

47. Mosley JG, Gibbs AC. Premature grey hair and hair loss among smokers: a new opportunity for health education? BMJ 1996;313:1616.

48. Gathers RC, McMichael AJ. Hair disorders in systemic disease. Dermatologic Signs of Internal Disease. Ed. Callen J, Jorizzo J, Bolgnia JL, et al. 4th ed. Elsevier: Saunders. 2003.

49. Özdemir M. Telojen Saç Dökülmesi. Türkiye Klinikleri Journal of Internal Medical Sciences 2006:2;6-9.

50. Sperling LC. Hair and systemic disease. Dermatol Clin 2001;19:711-26.

51. Goh C, Finkel M, Christos PJ, Sinha AA. Profile of 513 patients with alopecia areata: associations of disease subtypes with atopy, autoimmune disease and positive family history. J Eur Acad Dermatol Venereol 2006;20:1055-60. [CrossRef]

52. Olsen EA, Reed KB, Cacchio PB, Caudill L. Iron deficiency in female pattern hair loss, chronic telogen effluvium, and control groups. J Am Acad Dermatol 2010;63:991-9. [CrossRef]

53. Paus R, Olsen EA, Messenger AG. Hair growth disorders. Fitzpatrick.s Dermatology in General Medicine. Wolff K, Goldsmith LA, Katz SI, Gilchrest BA, Paller AS, Leffell DJ,editors. 7.Ed. New York: McGrawHill Companies; 2008.p.753.

54. Karakuzu A. Primer sikatrisyel alopesiler/Primary cicatricial alopecia. Turkderm 2014: 48:56-59. [CrossRef]

55. Sharma VK, Dawn G, Kumar B. Bubble hair: case caused by an overheating hair dryer and reproducibility in normal hair with heat. Journal of the American Academy of Dermatology 1994:30:54-60. [CrossRef]

56. Detwiler SP, Carson JL, Woosley JT, Gambling TM, Briggaman RA. Bubble hair. Case caused by an overheating hair dryer and reproducibility in normal hair with heat. J Am Acad Dermatol 1994;30:54-60.

57. Wilborn WS. Disorders of hair growth in African Americans. In: Olsen EA, editor.Disorders of hair growth: Diagnosis and treatment. Newyork: Mcgraw-Hill Inc. 1994.p.389า-407.

58. Whiting DA. Chronic telogen effluvium: increased scalp hair shedding in middle-aged women. J Am Acad Dermatol 1996;35:899-906.

59. Jan V, Roudier-Pujol C. Prise en charge d'une alop.cie chez la femme. In: Annales de dermatologie et de v.n.r.ologie. Masson; 2000.

60. Niang SO, Kane A, Dieng MT, Sy TN, Diallo M, Ndiaye B. Alopecia in Senegalese women. Int J Dermatol 2005;44 Suppl 1:22-3. [CrossRef]

61. Zviak C. Ondulation permanente et d.frisage. Science des traitements capillaires. Paris: Masson; 1987. p. 183209.

62. Gummer CL. Cosmetics and hair loss. Clin Exp Dermatol 2002;27:418-21. [CrossRef]

63. Draelos ZK. Hair cosmetics. Dermatol Clin 1991;9:19-27. [CrossRef]

64. Zviak C.Permanent waving and hair straightening. In: Zviak C, editor. The Science of hair care.Newyork: Marcel Dekker 1986. [CrossRef]

65. Courtois M, Loussouarn G, Hourseau C, Grollier JF. Ageing and hair cycles. Br J Dermatol 1995;132:86-93. [CrossRef]

66. Kutlubay Z, Bağlam S, Ergin B, Serdaroğlu S. Male androgenetic alopecia. Turkderm 2014:48:36-39. [CrossRef]

67. Birch MP, Messenger JF, Messenger AG. Hair density, hair diameter and the prevalence of female pattern hair loss. Br J Dermatol 2001;144:297-304. [CrossRef]

68. Mostafa WZ, Assaf MI, Ameen IA, El Safoury OS, Al Sulh SA. Hair loss in pityriasis versicolor lesions: a descriptive clinicopathological study. J Am Acad Dermatol 2013;69:19-23. [CrossRef]

69. Barman JM, Pecoraro V, Astore I. Method, Technic and Computations in the Study of the Trophic State of the Human Scalp Har. J Invest Dermatol 1964;42:421-5. [CrossRef]

70. Bolognia J, Schaffer J, Cerroni L. Dermatology. Vol 1. Madrid: Elsevier; 2004.

71. Yücel A, Aksungur VL, Denli YG, Özpoyraz M. Yağlı Saç ve Bakımı. Turkiye Klinikleri J Cosmetol 2004;5:68-70.

72. Pierard-Franchimont C, Pierard GE. Approche physiopathologique de la s.borrh.e du cuir chevelu. In: Annales de dermatologie et de v.n.r.ologie. Masson; 1988.

73. Rony HR, Zakon SJ. Effect of endocrine substances on the adult human scalp. Arch Derm Syphilol 1945;52:323-7. [CrossRef]

74. Banka N, Bunagan MJ, Dubrule Y, Shapiro J. Wigs and hairpieces: evaluating dermatologic issues. Dermatol Ther 2012;25:260-6. [CrossRef]

75. Malkud S.Telogen Effluvium: A Review. J Clin Diagn Res 2015;9:WE01-3. [CrossRef]

76. Braun-Falco O, Plewig G, Wolff HH. Dermatologie und venerologie. Verlag Berlin Heidelberg: Springer; 2013.

77. Gan DC, Sinclair RD. Prevalence of male and female pattern hair loss in Maryborough. J Investig Dermatol Symp Proc 2005;10:184-9.

78. Nnoruka N, Obiagboso I, Maduechesi C. Hair loss in children in South-East Nigeria: common and uncommon cases. International journal of dermatology 2007;46:18-22. [CrossRef]

79. Cash TF, Price VH, Savin RC. Psychological effects of androgenetic alopecia on women: comparisons with balding men and with female control subjects. J Am Acad Dermatol 1993;29:568-75. [CrossRef]

80. Güleç AT, Tanriverdi N, Dürü C, Saray Y, Akçali C. The role of psychological factors in alopecia areata and the impact of the disease on the quality of life. Int J Dermatol 2004;43:352-6. [CrossRef]

81. de Hollanda TR, Sodré CT, Brasil MA, Ramos-E-Silva M. Quality of life in alopecia areata: a case-control study. Int J Trichology 2014;6:8-12. [CrossRef] 